\title{
PHENOTYPIC AND GENOTYPIC PROPERTIES OF BRADYRHIZOBIA NODULATING LEGUMINOUS PLANTS OF THE GLYCINE, VIGNA AND LUPINUS GENERA
}

\author{
D.V. Krutylo \\ Institute of Agricultural Microbiology and Agro-industrial Manufacture, \\ National Academy of Agrarian Sciences, \\ 97 Shevchenko St., Chernihiv, 14027, Ukraine \\ e-mail:krutylodv@gmail.com
}

\begin{abstract}
Objective. To study phenotypic and genotypic features of nodule bacteria-microsymbionts of leguminous plants of the Glycine, Vigna and Lupinus genera. Methods. Serological affinity of 12 rhizobia strains was determined in agglutination reactions. Host specificity of strains was studied in vegetation experiments. RFLP analysis of rpoB gene was performed using MspI, HaeIII and NdeII restrictases. Sequencing of the 16S-23S rDNA intergenic spacer of rhizobia was performed on ABI 3130 Genetic Analyzer. Results. It was established that studied rhizobia strains differ significantly in serological properties and belong to 7 serogroups: KB11, M8, 1967, 46, B1, B2 and 367a. Microsymbionts of soybean, cowpea and mung bean form the group of cross inoculation, however, are unable to infect lupine. Alternatively, lupine rhizobia B. lupini $367 a$ and Bradyrhizobium sp. ЛД4, enter into symbiotic interactions with lupine, however, they do not nodulate soybean. B. japonicum 631 strain is capable of symbiosis with leguminous plants of different tribes: Phaseoleae and Lupineae. Based on RFLP analysis of rpoB gene, rhizobia were grouped into four clusters with following microsymbionts: I - cowpea, II - mung bean and soybean, III - slow-growing soybean nodule bacteria, IV - lupine rhizobia and intensive-growing soybean rhizobia. 16S-23S rDNA sequencing confirmed pertinence of soybean rhizobia to the B. japonicum species (USDA 4, USDA 6, USDA 123 genetic groups). This species also included mung bean microsymbionts (USDA 4 group). Bradyrhizobium sp. B11 isolate was obtained for the first time from cowpea nodules, and it was identified as a new B. diazoefficiens species (USDA 110 group). ITS regions of B. lupini 367 a and Bradyrhizobium sp. ЛД4 rhizobia were found to be identical. B. japonicum 631 strain has a 100\% similarity with B. lupini 367 a strain according to $16 \mathrm{~S}-23 \mathrm{~S} r \mathrm{DNA}$, and with high degree of probability can be included to B. lupini species. Conclusions. Serological heterogeneity of rhizobia from root nodules of plants of the Glycine, Vigna and Lupinus genera has been demonstrated. It was established that microsymbionts of soybean, cowpea and mung bean belong to one group of cross inoculation. 16S-23S rDNA sequencing allowed to classify the studied strains as different genetic groups and identify them as B. japonicum, B. diazoefficiens and B. lupini. The serological grouping of nodule bacteria was found to coincide with the genetic (rpoB gene and ITS region) grouping, and their host specificity was related to species affiliation.
\end{abstract}

Keywords: Bradyrhizobium japonicum, B. diazoefficiens, B. lupini, RFLP analysis, 16S-23S rDNA, rpoB gene, soybean, cowpea, mung bean, lupine.

The Bradyrhizobium genus was described in the early eighties of the last century and combined the slow-growing nodule bacteria - microsymbionts of various legumes. The first described species of this genus was B. japonicum [1,2]. Further isolated rhizobia were assigned to other species: $B$. elkanii [3], B. liaoningense [4] and B. yuanmingense [5]. The taxonomic status of Bradyrhizobium is constantly changed and renewed. Currently, 53 species of slow-growing nodule bacteria are known, in which 39 have valid names [6]. The accumulation of experimental data on the genetic heterogeneity of rhizobia in natural ecosystems and agrocenoses suggests that new Bradyrhizobium species still need to be identified and described $[6,7]$.

It was believed for a long time that B. japonicum bacteria can only infect soybean (Glycine genus). However, later it turned out that the range of their host plants could be much wider. They were isolated from the nodules of various species of cowpea (Vigna genus) [8], lupine (Lupinus genus) 
and other legumes [9]. At the same time, these legumes can form a symbiosis with representatives of other types of rhizobia.

It was found that nodule bacteria with different growth rates may form symbiotic relationships with soybean, namely: slow-growing B. japonicum [1], B. elkanii [3], B. diazoefficiens [10], B. liaoningense [4], B. yuanmingense [4] and fast-growing Ensifer (Sinorhizobium) fredii, S. xinjiangensis [11] and Mesorhizobium tianshanense [12].

More than 20 species of rhizobia were isolated and identified from cowpea nodules $[13,14]$. The roots of this plant can be simultaneously infected by nodule bacteria of several genera, in particular Bradyrhizobium and Rhizobium [14, 15].

Microsymbionts of lupine are slow-growing nodule bacteria $B$. lupini, which recently was referred to the Rhizobium lupini species [16]. Furthermore, it is known from the literature that the European species of lupine can be infected by $B$. canariense and B. japonicum nodule bacteria $[6,9]$, and American species - B. japonicum and $B$. elkanii [17]. Some reports indicate that nodules on the roots of lupine are also formed by the representatives of the Allorhizobium, Mesorhizobium, Sinorhizobium and Rhizobium genera [18, 19].

It should be noted that typical soybean microsymbionts in soils of Ukraine are slow-growing nodule bacteria of the $B$. japonicum species. Earlier among their representatives we identified strains that are characterized by increased growth rate and conventionally called "strains with intensive growth". These strains have a set of characteristic features and differ from the typical slow-growing soybean rhizobia by morphological, cultural, physiological, chemotaxonomic and genetic properties [20,21]. It is believed that lupine microsymbionts in Ukrainian soils can be rhizobia of the $B$. lupini species. Cowpea plants can form a symbiosis with rhizobia of various genera, including B. japonicum.

We have not found data on infection of soybean and lupine with other types of rhizobia in Ukrainian scientific literature. Only some properties of B. japonicum 631, which is capable of forming nodules on soybean and lupine roots, have been studied [22]. The heterogeneity of nodule bacteria of the Bradyrhizobium genus requires further study using serological and molecular genetic methods. Different experimental approaches will allow to fully characterize rhizobia, establish their affinity and reveal peculiarities of formation and functioning of symbiotic systems with different legumes.

Taking into account the above, the objective of our work was to study the phenotypic and genotypic features of nodule bacteria - microsymbionts of legume plants of the Glycine, Vigna and Lupinus genera.

Materials and methods. The objects of study were soybean nodule bacteria strains with slow (Bradyrhizobium japonicum 46, B. japonicum KC23) and intensive (B. japonicum KB11, $B$. japonicum KC19) growth rates, B. japonicum VKM B-1967 = USDA $6^{\mathrm{T}}$ strain; B. japonicum 631 strain isolated from soybean nodules and capable to infect soybean and lupine (strain from the collection of microorganism of the All-Russian Research Institute of Agricultural Microbiology of RAAS, St. Petersburg, Russia); B. lupini 367a standard strain of lupine nodule bacteria; rhizobia isolated from nodules of cowpea (Bradyrhizobium sp. B11, Bradyrhizobium sp. B22), mung bean (Bradyrhizobium sp. KM1, Bradyrhizobium sp. KM2) and lupine (Bradyrhizobium sp. ЛД4); plants of soybean (Glycine max (L.) Merr., variety Ustia), cowpea (Vigna unguiculata (L.) Walp., UD0301857), mung bean (Vigna radiata (L.) Wilczek, variety Tadzhytskyi 1), white (Lupinus albus L., variety Lybid') and yellow (Lupinus luteus L., variety Chernihivets) lupine. Rhizobial strains are stored in the collection of the Laboratory of Plant-Microbial Interactions and in the Collection of useful soil microorganisms at the Institute of Agricultural Microbiology and Agroindustrial Manufacture of the National Academy of Sciences of Ukraine.

In this work, immune antisera against active strains of nodule bacteria of soybean $B$. japonicum (46, M8, KB11, 3646, 1967, OR, HR, NR), microsymbionts of cowpea Bradyrhizobium sp. (B1, B2) and lupine B. lupini (301, 367a) were used. Pertinence of the studied strains of nodule bacteria to a certain serogroup was determined in the agglutination reaction by the Gruber-Vidal method [23].

The ability of nodule bacteria strains to enter into a symbiotic relationship with soybean, cowpea, mung bean, white and yellow lupine (seeds were provided by the NSC "Institute of Agriculture of the National Academy of Agrarian Sciences of Ukraine" and V.Ya. Yuryev National Centre for Plant Genetic Resources of NAAS of Ukraine) were studied in vegetative experiments. Cultivation of nodule bacteria was carried out in 
flasks (750 ml) on liquid medium (for 72 hours), containing $(\mathrm{g} / \mathrm{l}): \mathrm{K}_{2} \mathrm{HPO}_{4}-0.5, \mathrm{KH}_{2} \mathrm{PO}_{4}-0.5$, $\left(\mathrm{NH}_{4}\right)_{2} \mathrm{SO}_{4} \cdot 7 \mathrm{H}_{2} \mathrm{O}-1.0, \mathrm{MgSO}_{4} \cdot 7 \mathrm{H}_{2} \mathrm{O}-0.2$, $\mathrm{NaCl}-0.2, \mathrm{CaCO}_{3}$ (sterile) -0.1 , sucrose -2.0 , mannitol -3.0 , glucose -10.0 , broth of peas (peas seeds -50 g per 1 litre of water) $-100.0 \mathrm{ml} / \mathrm{l} ; \mathrm{pH}$ 7.0-7.2. The titre of bacteria was $2 \cdot 10^{9} \mathrm{CFU} / \mathrm{ml}$ (colony-forming units per milliliter). Inoculation load was 200-300 thousand cells per 1 seed. Plants were grown in a 2.51 vessel on sterile vermiculite wetted with $0.2 \% \mathrm{KH}_{2} \mathrm{PO}_{4}$ ). The variants without inoculation were used as the controls. The repetition of the experiment was quadruple. Activity of symbiotic nitrogen fixation was measured in flowering phase by acetylene method [24].

Nodule bacteria were cultivated in TY agar medium at $28^{\circ} \mathrm{C}$ [25]. Total DNA was extracted from the pure cultures of nodule bacteria in exponential growth phase using a "DNA-sorb B" kit. FGPS 1490-72 (5'-tgcggetggatccectcctt-3') and FGPL132-38 (5'-ccgggtttccccatt-3') primers were used for amplification of 16S-23S rRNA intergenic spacer (ITS region) [26, 27]. The temperaturetime profile of amplification: denaturation at $94^{\circ} \mathrm{C}$ for $30 \mathrm{sec}$, primers annealing at $55^{\circ} \mathrm{C}$ for $30 \mathrm{sec}$, and synthesis of complementary chain at $72^{\circ} \mathrm{C}$ for $1 \mathrm{~min}$ ( 30 cycles). The primers FGPS1490-72/FGPL132-38 successfully yielded PCR amplicons (835-860 bp). Sequencing was performed on ABI 3130 Genetic Analyzer. Comparative analysis of sequences obtained and sequences from GenBank database was performed using BLASTN software (version 2.9.0). Equalization of the sequences was done using the CLUSTAL W program [28]. The phylogenetic tree was plotted using Mega 6 software [29] via Neighbor-Joining algorithm [30].

RFLP analysis (restriction fragments length polymorphism) of rpoB gene was performed for typing of nodule bacteria strains and determination of their affinity.

RpoB83F (5'-cctcatcgaggttcagaaggc-3') and rpoB1061R (5'-agcgtgttgcggatataggcg-3') primers were used for amplification the rpoB gene [31]. The temperature-time profile of amplification: denaturation at $94^{\circ} \mathrm{C}$ for $5 \mathrm{~min}, 4$ cycles, $94^{\circ} \mathrm{C}$ for $2 \mathrm{~min}, 58^{\circ} \mathrm{C}$ for $2 \mathrm{~min}, 72^{\circ} \mathrm{C}$ for $1 \mathrm{~min}, 31$ cycles, $94^{\circ} \mathrm{C}$ for $30 \mathrm{sec}, 58^{\circ} \mathrm{C}$ for $1 \mathrm{~min}, 72^{\circ} \mathrm{C}$ for $1 \mathrm{~min}$, final elongation at $72^{\circ} \mathrm{C}$ for $7 \mathrm{~min}$.

The restriction analysis (RFLP) was carried out with the use of restriction endonuclease MspI, HaeIII, NdeII (Fermentas, USA) according to the manufacturer's instruction. DNA processed by restrictase was analyzed with the use of electrophoresis in $2.5 \%$ agarose gel. The DNA fragments size was calculated using Total Lab software (version 2.01).

The affinity of the resulting RFLP profiles of rpoB gene was compared using DendroUPGMA software (http://genomes.urv.cat/UPGMA/) based on unweighted pair-group method using arithmetic averages (UPGMA).

Results. Slow- and intensive-growing soybean nodule bacteria strains, as well as isolates from nodules of cowpea, mung bean and lupine were used in the work. Earlier, during study of the morphological and cultural properties of these microorganisms, it was found that they belong to the Bradyrhizobium genus. Soybean microsymbionts by phenotypic and genotypic features (identification of $16 \mathrm{~S}$ rRNA gene nucleotide sequence) were classified as B. japonicum [20].

Serological method is a relatively simple and sufficiently informative method for investigating the diversity and affinity of nodule bacteria.

Serological properties of nodule bacteria were studied in the agglutination reaction. It has been established that the slow-growing strains of soybean rhizobia B. japonicum 1967, B. japonicum $46, B$. japonicum $\mathrm{KC} 23$ are serologically different and belong to three serogroups: 1967 , 46 and M8, respectively (Table 1). Intensivegrowing B. japonicum $\mathrm{KB} 11$ and B. japonicum KC19 strains react positively with KB11 antiserum, and we have incorporated them in a separate serological group KB11. Mung bean microsymbionts Bradyrhizobium sp. KM1 and Bradyrhizobium sp. KM2 were classified as serogroup M8. The obtained results indicate their affinity with $B$. japonicum M8 strain. Isolates from cowpea nodules Bradyrhizobium sp. B11 and Bradyrhizobium sp. B22 differ in antigenic composition and belong to two serogroups: B1 and $\mathrm{B} 2$, respectively. The standard strain of lupine rhizobia B. lupini 367 a and B. japonicum 631 strain capable to infect soybean and lupine, belong to the same serological group 367a. At the same time, Bradyrhizobium sp. ЛД4 isolate does not react with used antisera and its serological pertinence remains undefined. It should also be noted that the studied strains of lupine nodule bacteria show a weak positive reaction with KB11 antiserum (obtained against the intensive-growing $B$. japonicum KB11 strain) in low dilutions (up to 1:50). This fact may indicate the presence of common antigenic 
determinants and serological similarity of lupine rhizobia and intensive-growing soybean rhizobia.

Despite the serological heterogeneity of investigated nodule bacteria, several serological groups (KB11, M8, and 367a) that combine strains similar in antigenic composition can be identified.

Under vegetative experiment conditions, the host specificity of the nodule bacterial strains was studied, that is, their ability to form nitrogen fixing nodules on the roots of different species of legumes: Glycine max, Vigna unguiculata, Vigna radiata, Lupinus albus and Lupinus luteus (Table 1).

It was shown that soybean microsymbionts (B. japonicum 46, B. japonicum KC23, B. japonicum KB11, B. japonicum KC19), cowpea
(Bradyrhizobium sp. B11, Bradyrhizobium sp. B22) and mung bean (Bradyrhizobium sp. KM1, Bradyrhizobium sp KM2) are capable of crossinfection with these three legumes (phenotype $\mathrm{Nod}^{+} \mathrm{Fix}^{+}$and $\mathrm{Nod}^{+} \mathrm{Fix}-$ ), but they are not capable of forming nodules on the lupine roots (phenotype Nod-). Standard lupine nodule bacteria strain B. lupini 367a and Bradyrhizobium sp. ЛД4 isolate, conversely, formed active symbiotic relationship with lupine (phenotype $\mathrm{Nod}^{+} \mathrm{Fix}^{+}$), but did not infect soybean (phenotype Nod-). It should be noted that B. japonicum 631, isolated from soybean nodules, was able to form active nitrogen fixing nodules (phenotype $\mathrm{Nod}^{+} \mathrm{Fix}^{+}$) on the roots of plants of different tribes: soybean (Phaseoleae tribe) and lupine (Lupineae tribe).

\section{Table 1}

Host specificity and serological affinity of rhizobia strains isolated from soybean, cowpea, mung bean and lupine nodules

\begin{tabular}{|c|c|c|c|c|c|c|c|}
\hline \multirow{3}{*}{ Strains (isolates) } & \multirow{3}{*}{$\begin{array}{l}\text { Host- } \\
\text { plants }\end{array}$} & \multirow{3}{*}{$\begin{array}{l}\text { Sero- } \\
\text { groups }\end{array}$} & \multicolumn{5}{|c|}{ Symbiotic phenotypes } \\
\hline & & & \multicolumn{3}{|c|}{ Phaseoleae tribe } & \multicolumn{2}{|c|}{ Lupineae tribe } \\
\hline & & & $\begin{array}{c}\text { Glycine } \\
\text { max }\end{array}$ & $\begin{array}{c}\text { Vigna } \\
\text { uinguiculata }\end{array}$ & $\begin{array}{c}\text { Vigna } \\
\text { radiata }\end{array}$ & $\begin{array}{c}\text { Lupinus } \\
\text { albus }\end{array}$ & \begin{tabular}{|c|} 
Lupinus \\
luteus
\end{tabular} \\
\hline B. japonicum KB11 & soybean & \multirow{2}{*}{ KB11 } & $\mathrm{Nod}^{+} \mathrm{Fix}^{+}$ & $\operatorname{Nod}^{+} \mathbf{F i x}^{-}$ & $\mathrm{Nod}^{+} \mathrm{Fix}^{+}$ & Nod $^{-}$ & Nod $^{-}$ \\
\hline B. japonicum KC19 & soybean & & $\mathrm{Nod}^{+} \mathrm{Fix}^{+}$ & $\operatorname{Nod}^{+} \mathbf{F i x}^{-}$ & $\mathrm{Nod}^{+} \mathrm{Fix}^{+}$ & Nod $^{-}$ & Nod $^{-}$ \\
\hline B. japonicum 1967 & soybean & 1967 & $\mathrm{Nod}^{+} \mathrm{Fix}^{+}$ & $\mathrm{Nod}^{+} \mathrm{Fix}^{+}$ & $\operatorname{Nod}^{+} \mathrm{Fix}^{+}$ & Nod $^{-}$ & Nod $^{-}$ \\
\hline B. japonicum 46 & soybean & 46 & $\mathrm{Nod}^{+} \mathrm{Fix}^{+}$ & $\mathrm{Nod}^{+} \mathrm{Fix}^{+}$ & $\mathrm{Nod}^{+} \mathrm{Fix}^{+}$ & Nod $^{-}$ & Nod $^{-}$ \\
\hline B. japonicum KC23 & soybean & \multirow{3}{*}{ M8 } & $\mathrm{Nod}^{+} \mathrm{Fix}^{+}$ & $\mathrm{Nod}^{+} \mathrm{Fix}^{+}$ & $\operatorname{Nod}^{+} \mathrm{Fix}^{+}$ & Nod $^{-}$ & Nod $^{-}$ \\
\hline Bradyrhizobium sp. KM1 & $\begin{array}{l}\text { mung } \\
\text { bean }\end{array}$ & & $\mathrm{Nod}^{+} \mathrm{Fix}^{+}$ & $\mathrm{Nod}^{+} \mathrm{Fix}^{+}$ & $\operatorname{Nod}^{+} \mathrm{Fix}^{+}$ & Nod $^{-}$ & Nod $^{-}$ \\
\hline Bradyrhizobium sp. KM2 & $\begin{array}{l}\text { mung } \\
\text { bean }\end{array}$ & & $\mathrm{Nod}^{+} \mathrm{Fix}^{+}$ & $\operatorname{Nod}^{+} \mathrm{Fix}^{+}$ & $\operatorname{Nod}^{+} \mathrm{Fix}^{+}$ & Nod $^{-}$ & Nod $^{-}$ \\
\hline Bradyrhizobium sp. B11 & cowpea & B1 & $\operatorname{Nod}^{+} \mathrm{Fix}^{+}$ & $\mathrm{Nod}^{+} \mathrm{Fix}^{+}$ & $\operatorname{Nod}^{+} \mathrm{Fix}^{+}$ & Nod $^{-}$ & Nod $^{-}$ \\
\hline Bradyrhizobium sp. B22 & cowpea & B2 & $\mathrm{Nod}^{+} \mathrm{Fix}^{+}$ & $\mathrm{Nod}^{+} \mathrm{Fix}^{+}$ & $\operatorname{Nod}^{+} \mathrm{Fix}^{+}$ & Nod $^{-}$ & Nod $^{-}$ \\
\hline B. japonicum 631 & soybean & \multirow{2}{*}{$367 a$} & $\mathrm{Nod}^{+} \mathrm{Fix}^{+}$ & - & - & $\mathrm{Nod}^{+} \mathrm{Fix}^{+}$ & $\mathrm{Nod}^{+} \mathrm{Fix}$ \\
\hline B. lupini 367a & lupine & & Nod $^{-}$ & - & - & $\mathrm{Nod}^{+} \mathrm{Fix}^{+}$ & $\mathrm{Nod}^{+} \mathrm{Fix}$ \\
\hline Bradyrhizobium sp. ЛД4 & lupine & $\mathrm{X}$ & Nod $^{-}$ & - & - & $\mathrm{Nod}^{+} \mathrm{Fix}^{+}$ & $\mathrm{Nod}^{+} \mathrm{Fix}$ \\
\hline
\end{tabular}

Legends: $\mathrm{Nod}^{+} \mathrm{Fix}^{+}-$formation of nitrogen-fixing nodules; $\mathrm{Nod}^{+} \mathrm{Fix}^{-}-$formation of nodules that do not fix nitrogen, $\mathrm{Nod}^{-}-$nodules are not formed, - - not investigated, $\mathrm{X}-$ undetermined serological group.

It is known that genes of the ribosomal cluster (16S rRNA and 16S-23S rRNA), as well as functionally important genes (housekeeping genes), are widely used to assess the diversity of microorganisms and determine their species specificity. We have performed a restriction analysis of one of these genes, namely the gene rpoB that encodes the $\beta$-subunit of RNA polymerase and can be used as a highly conserved genetic marker [31, 32].

When amplifying rpoB gene in the studied rhizobia, one fragment of $\sim 900 \mathrm{bp}$ was formed which was separately cleaved with restriction enzymes MspI, HaeIII and NdeII. 
Under the use of MspI, nodule bacteria, regardless of species, had the same restriction patterns and were classified as MI rpoB type (Table 2). Only the typical B. japonicum 1967 was different from the others strains and isolates by the number of DNA fragments and formed the MII rpoB type.

Significant differences among the nodule bacteria were detected with the use of restriction endonucleases HaeIII and NdeII.

Upon cleavage of the rpoB gene with HaeIII restriction enzyme, from three to five DNA fragments were formed, which allowed strains to be classified into five restriction types. Intensivegrowing soybean rhizobia B. japonicum KB11, $B$. japonicum KC19, standard lupine strain B. lupini $367 \mathrm{a}$ and $B$. japonicum 631 had identical set of fragments and formed the HI rpoB type. Typical B. japonicum 1967 strain was characterised by the unique restriction pattern - NII rpoB type. The B. japonicum 46 strain and isolated from lupine nodules Bradyrhizobium sp. ЛД4 strain (HIII rpoB type) were similar. Microsymbionts of soybean and mung bean (B. japonicum $\mathrm{KC23}$, Bradyrhizobium sp. KM1 and Bradyrhizobium sp. KM2) were combined into HIV rpoB type. Isolates derived from cowpea nodules Bradyrhizobium sp. B11 and Bradyrhizobium sp. B22 are classified as HV rpoB type.
Four types of DNA patterns were formed under the use of restriction endonuclease NdeII. Therefore, intensive-growing strains of soybean rhizobia B. japonicum KB11, B. japonicum KC19, lupine rhizobia B. lupini 367a, Bradyrhizobium sp. ЛД4 and В. japonicum 631 had identical profiles and they are combined into one rpoB type (NI). They differed from the slow-growing $B$. japonicum 1967 and B. japonicum 46 strains, which were classified as NII rpoB type with 4 fragments in restriction profiles. The largest number of fragments (6 units) was observed in the strains of the slow-growing $B$. japonicum $\mathrm{KC} 23$ and mung bean microsymbionts Bradyrhizobium sp. KM1, Bradyrhizobium sp. KM2 (NIII rpoB type). Isolates of Bradyrhizobium sp. B11 and Bradyrhizobium sp. B22 formed the NIV rpoB type.

Based on RFLP analysis of rpoB gene, using three restrictases, we have plotted UPGMA dendrogram of relationships of 12 strains and isolates of nodule bacteria - microsymbionts of different legumes (Fig. 1).

As can be seen from the diagram, the studied microorganisms were divided into four clusters (I-IV). A separate group was formed by intensive-growing strains of soybean rhizobia B. japonicum KB11, B. japonicum KC19, strains of lupine nodule bacteria B. lupini 367a, Bradyrhizobium sp. ЛД4 and В. japonicum 631,

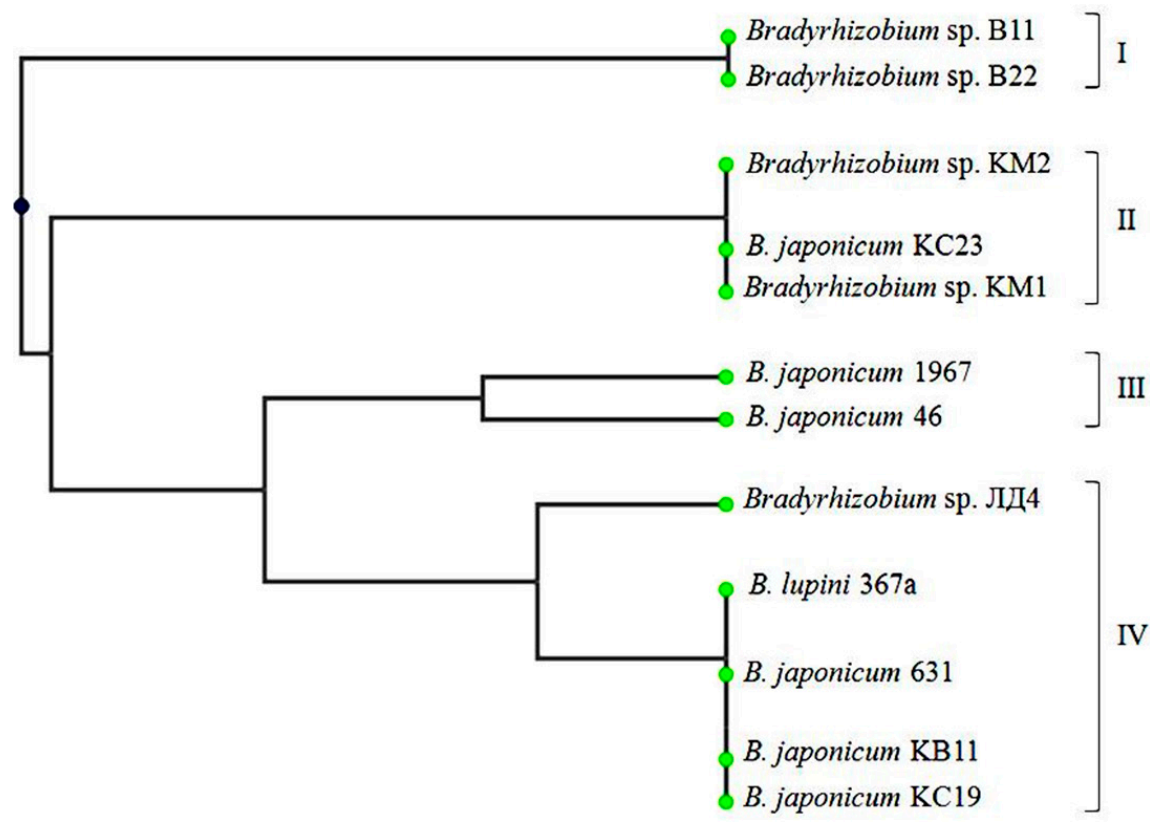

F i g. 1. UPGMA dendrogram, showing clustering of strains and isolates of soybean, cowpea, mung bean and lupine nodule bacteria based on RFLP analysis of rpoB gene for the use of restriction enzymes MspI, HaeIII and NdeII. 


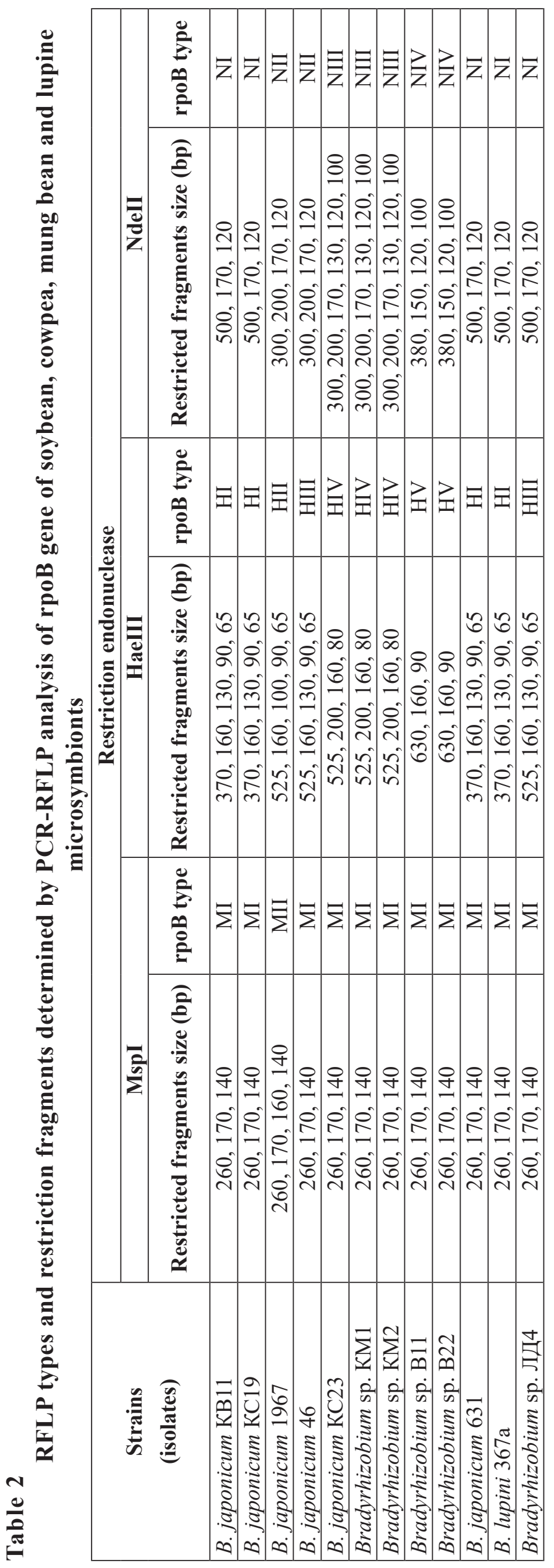


indicating their close phylogenetic affinity. At the same time, the slow-growing strains of soybean nodule bacteria B. japonicum 1967, B. japonicum 46 and B. japonicum $\mathrm{KC} 23$ turned out to be phylogenetically distant from lupine microsymbionts, and they entered into two different clusters. One cluster combined similar strains of B. japonicum 1967 and B. japonicum 46 , while another cluster included mung bean microsymbionts Bradyrhizobium sp. KM1 and Bradyrhizobium sp. KM2 along with B. japonicum $\mathrm{KC} 23$. The genetic similarity on the dendrogram has been demonstrated by cowpea microsymbionts Bradyrhizobium sp. B11 and Bradyrhizobium sp. B22.
We have performed 16S-23S rDNA sequencing (ITS region) to identify isolates of nodule bacteria and to specify the species affiliation of strains. The resolution of this genetic marker is quite high and allows to find differences between microorganisms at the interspecies level.

The analysis of 16S-23S rDNA nucleotide sequences and their comparison with the sequence of $B$. japonicum USDA $6^{\mathrm{T}}$ and $B$. japonicum strains from GenBank confirmed the pertinence of soybean microsymbionts to B. japonicum species (Table 3 ). As can be seen from the filogram (Fig. 1), the studied strains form three separate genetic groups by $99.0-100.0 \%$ of the support level: USDA 6 (B. japonicum 1967, B. japonicum 46), USDA 4 (B. japonicum KC23), USDA 123 (B. japonicum KB11 and B. japonicum KC19).

Table 3

Identity of nucleotide sequences 16S-23S rDNA of microsymbionts of soybean, cowpea, mung bean and lupine with ITS sequences of nodule bacteria of the Bradyrhizobium genus

\begin{tabular}{|c|c|c|}
\hline Strains (isolates) & $\begin{array}{c}\text { Reference strains } \\
\text { (GenBank accession numbers) }\end{array}$ & Similarity by ITS, \% \\
\hline \multirow{2}{*}{ B. japonicum KB11 } & B. japonicum USDA 127 (AF208508) & 99.8 \\
\hline & B. japonicum USDA 123 (AF208504) & 99.5 \\
\hline \multirow{2}{*}{ B. japonicum КС19 } & B. japonicum USDA 127(AF208508) & 99.8 \\
\hline & B. japonicum USDA 123 (AF208504) & 99.5 \\
\hline B. japonicum 1967 (USDA 6) & B. japonicum USDA $6^{\mathrm{T}}$ (HQ143390) & 100.0 \\
\hline B. japonicum 46 & B. japonicum USDA $6^{\mathrm{T}}$ (HQ143390) & 98.7 \\
\hline B. japonicum $\mathrm{KC} 23$ & B. japonicum USDA 4 (AF208515) & 99.1 \\
\hline \multirow{2}{*}{ Bradyrhizobium sp. KM1 } & B. japonicum USDA 4 (AF208515) & 99.1 \\
\hline & B. japonicum $\mathrm{KC} 23$ & 100.0 \\
\hline \multirow{2}{*}{ Bradyrhizobium sp. KM2 } & B. japonicum USDA 4 (AF208515) & 99.1 \\
\hline & B. japonicum $\mathrm{KC} 23$ & 100.0 \\
\hline \multirow{2}{*}{ Bradyrhizobium sp. B11 } & B. diazoefficiens USDA $110^{\mathrm{T}}$ (AF338865) & 100.0 \\
\hline & B. diazoefficiens XF7 (CP029603) & 100.0 \\
\hline \multirow{3}{*}{ Bradyrhizobium sp. B22 } & B. lupini $367 \mathrm{a}$ & 100.0 \\
\hline & B. japonicum USDA $6^{\mathrm{T}}$ (HQ143390) & 93.1 \\
\hline & B. diazoefficiens USDA $110^{\mathrm{T}}$ (AF338865) & 93.7 \\
\hline \multirow{3}{*}{ B. japonicum 631} & B. lupini $367 \mathrm{a}$ & 100.0 \\
\hline & B. japonicum USDA $6^{\mathrm{T}}$ (HQ143390) & 93.1 \\
\hline & B. japonicum USDA 123 (AF208504) & 96.6 \\
\hline \multirow{2}{*}{ B. lupini $367 \mathrm{a}$} & B. lupini FIV88 & 100.0 \\
\hline & B. japonicum USDA 123 (AF208504) & 96.6 \\
\hline \multirow{2}{*}{ Bradyrhizobium sp. ЛД4 } & B. lupini $367 \mathrm{a}$ & 100.0 \\
\hline & B. japonicum USDA 123 (AF208504) & 96.6 \\
\hline
\end{tabular}


According to the structure of the ITS region, isolates from mung bean nodule Bradyrhizobium sp. KM1 and Bradyrhizobium sp. KM2 is $99.1 \%$ similar to the $B$. japonicum USDA 4 strain deposited in GenBank (Table 3). The highest level of homology $(100.0 \%)$ of these strains was noted with $B$. japonicum $\mathrm{KC} 23$ strain selected by us, which also belongs to USDA 4 genetic group (Fig. 2) and serologic group M8 (Table 1). Based on the sequencing results of $16 \mathrm{~S}-23 \mathrm{~S}$ rRNA intergenic spacer, the study of the structure of the rpoB gene, as well as the analysis of serological affinity and symbiotic properties, mung bean microsymbionts were identified as B. japonicum.

Cowpea microsymbionts entered into two different statistically reliable clusters (Fig. 2) on the phylogenetic tree. ITS sequence of Brady- rhizobium sp. B11 isolate was found to be $100.0 \%$ similar to the sequences of soybean strains of B. diazoefficiens USDA $110^{\mathrm{T}}$ and B. diazoefficiens XF7 from GenBank (genetic group USDA 110). Considering the high degree of homology in the structure of 16S-23S rRNA intergenic region, this isolate can be classified as $B$. diazoefficiens. It should be noted that a relatively recent a group of strains of soybean and other legumes (B. japonicum group Ia), were reclassified to this species, and they closely interconnected but differ from the nodule bacteria $B$. japonicum by the phenotypic and genotypic features [10].

The second isolate from nodules of cowpea Bradyrhizobium sp. B22 showed the maximum degree of ITS homology (100.0\%) with the standard B. lupini 367a strain and almost $100.0 \%$

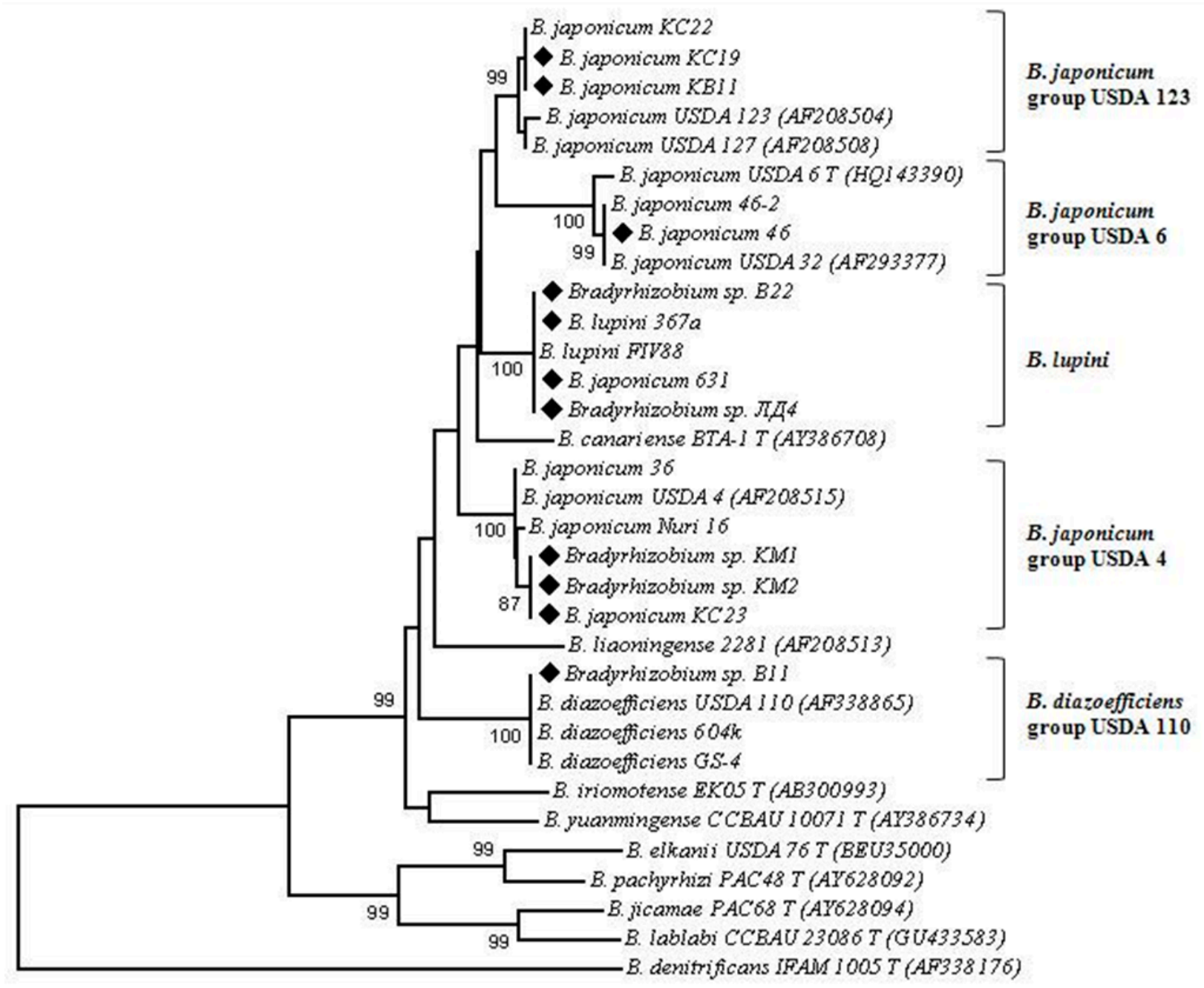

F i g. 2. Phylogenetic tree designed based on the comparative analysis of sequences of intergenic region 16S-23S rRNA of nodule bacteria with the use of the Neighbor-Joining algorithm. The scale corresponds with 2 substitutions to 100 founding pair (evolutionary distances). The figures show the statistical reliability of branching order (in \%), which is estimated with the help of "bootstrap" - the analysis of 1000 alternative tree. 
support level entered into a statistically significant cluster of $B$. lupini species bacteria. Considering that this strain is not able to infect yellow and white lupine, but forms nitrogen fixing nodules on soybean, cowpea and mung bean roots (Table 1), further molecular genetic studies are needed to clarify its systematic position.

All lupine microsymbionts entered into separate cluster on the ITS dendrogram with a $100.0 \%$. support level. The standard B. lupini 367 a strain showed $100.0 \%$ similarity to $B$. lupini FIV88, and ITS region of Bradyrhizobium sp. ЛД4 isolate was $100.0 \%$ identical to ITS region of $B$. lupini 367 a strain (Table 3 ). The fact that $B$. japonicum 631 , isolated from soybean nodules, had $100.0 \%$ homology with $B$. lupini 367 a strain is of particular importance. At the same time, the similarity of $16 \mathrm{~S}-23 \mathrm{~S}$ rDNA of this strain and the typical strain of soybean rhizobia $B$. japonicum USDA $6^{\mathrm{T}}$ was only $93.1 \%$, which is considered low for such a high-conservative locus. Strains of the same species cannot have less than $95.0 \%$ homology in ITS region $[33,34]$. Based on the obtained genetic data and the ability of the studied strain to nodulate not only soybean, but also lupine, it can be classified as $B$. lupini with high degree of probability.

Discussion. It is known that the intense cultivation of legumes promotes the increase of the biological diversity of their microsymbionts. New genotypes of nodule bacteria can occur as a result of mutations, recombinations, horizontal transfer of genes between strains of one species and another rhizobial microbiota [33].

In the modern literature, considerable attention is paid to the research of genetic resources and diversity of microsymbionts of both traditional and rare legumes. However, in Ukraine these issues remain virtually unexplored. Information on phenotypic and genotypic features of rhizobia can be useful in studying their population genetics, ecology, and also for agricultural practice $[33,35]$.

In this work, we have studied 12 strains and isolates of nodule bacteria - soybean, cowpea, mung bean and lupine microsymbionts. Their serological and genetic features, as well as the ability to form a symbiotic relationship with leguminous plants of different tribes: Phaseoleae (genus Glycine and Vigna) and Lupineae (genus Lupinus), have been studied.

We have established a significant genetic diversity of studied nodule bacteria. RFLP analysis of the rpoB gene allowed the grouping of nodule bacteria into four statistically reliable clusters. As a result of 16S-23S rDNA nucleotide sequences determination and comparing them with the standard and typical (from GenBank) strains, the rhizobia were classified into five genetic groups. In particular, three genetic groups were formed by representatives of $B$. japonicum species - soybean and mung bean microsymbionts. Rhizobia of $B$. diazoefficiens and $B$. lupini species were classified into two separate groups. It should be noted that we were the first who discovered B. diazoefficiens nodule bacteria in Ukrainian soils. They can form nodules on soybeans, cowpea and mung beans roots. The data that we obtained are consistent with the reports of scientists who studied the diversity of soybean nodule bacteria, cowpea and lupine in the soils of European, Asian, and African countries. The studies of Pudełko K. [19], Sikora S. [36], Appunu C. [37], Chidebe I. [38] et al. demonstrated a high degree of local rhizobia polymorphism according to the ITS region and housekeeping genes, which allowed to classify the strains into different genetic groups. Moreover, as in our studies, the number of formed groups depended on used genetic marker and restriction endonuclease [19, 36-39].

The serologic typing of Bradyrhizobium strains showed that they differ significantly in serological properties and belong to seven serogroups. Four serogroups (KB11, 1967, 46, M8) are microsymbionts of soybean and mung bean. And bacteria from root nodules of cowpea and lupine were included in three serogroups (B1, B2, 367a). A significant serological diversity of soybean and cowpea microsymbionts was revealed in the works of other scientists [40, 41].

Comparing the data obtained by us, a certain relationship was found between the grouping of microsymbionts by genetic markers and serological composition. For example, serologically related strains belonging to the serogroup KB11 formed a separate group according to the nucleotide sequences of 16S-23S rDNA and restriction profiles of rpoB gene. Similarly, the representatives of the serogroup M8 - microsymbionts of mung bean and B. japonicum $\mathrm{KC} 23$ strain were combined. It is noteworthy that nodule bacteria of various species of B. japonicum (intensive-growing strains) and $B$. lupini have similar antigenic determinants and entered into one cluster by RFLP profiles of rpoB gene. The obtained results may indicate their serological and genetic affinity.

There are few reports in the literature that link the serology of nodule bacteria with molecular 
genetic studies. For example, van Berkum et al. investigated the evolutionary relationships between 52 strains of soybean nodule bacteria, which belong to 17 serological groups. As a result, it was found that the strains within each serogroup had little difference in the nucleotide sequence of the 16S rDNA and ITS region. Correspondence of serological and genetic groups was confirmed by AFLP (amplified fragment length polymorphism) analysis. At the same time, B. liaoningense 2281 and $B$. japonicum USDA 135 strains cross-reacted in a serological reaction. We believe that the use of various experimental approaches and involvement of the higher number of strains is necessary for better understanding the relationship between serological and genetic organization of strains.

It should also be noted that the host specificity of the studied rhizobia strains corresponds to their genetic organization (ITS region). However, the relationship between plants and some strains does not fit into the scheme of their classification into species for the ability to infect one or other legumes. For example, we have obtained an isolate from cowpea nodules Bradyrhizobium sp. B22, which is identified as B. lupini by $100.0 \%$ homology in ITS region, but it is not capable to form nodules on white and yellow lupine roots. B. japonicum 631 strain, isolated from soybean nodules, is interesting. This strain is able to nodulate soybean and lupine, and according to the nucleotide sequence of ITS region can be classified as $B$. lupini. That is, for a more reliable determination of the boundaries of the species, complex polyphasic studies of Bradyrhizobium strains are required, as many researchers point out $[33,35]$.

Thus, we have shown the serological heterogeneity of rhizobia from root nodules of the Glycine, Vigna and Lupinus genera. It has been established that soybean, cowpea and mung bean microsymbionts belong to the same group of cross-inoculation. By the results of sequencing of ITS region, the studied strains examined were classified in different genetic groups and identified as B. japonicum, B. diazoefficiens and B. lupini. The serological grouping of nodule bacteria was found to coincide with the genetic (rpoB gene and ITS region) grouping, and their host specificity was related to species affiliation.

Further study of nodule bacteria - microsymbionts of different legumes will allow to establish more deeply the feature of their biodiversity formation in soils of Ukraine.

\section{ФЕНОТИПОВІ ТА ГЕНОТИПОВІ ВЛАСТИВОСТІ БРАДІРИЗОБІЙ, ЗДАТНИХ НОДУЛЮВАТИ БОБОВІ РОСЛИНИ РОДІВ GLYCINE, VIGNA TA LUPINUS}

\section{Д.В. Крутило}

Інститут сільськогосподарської мікробіології та агропромислового виробництва НААН, вул. Шевченка, 97, Чернігів, 14027, Україна

\section{Резюме}

Мета. Вивчити фенотипові та генотипові ознаки бульбочкових бактерій - мікросимбіонтів бобових рослин родів Glycine, Vigna та Lupinus. Методи. Серологічну спорідненість 12 штамів ризобій визначали у реакції аглютинації. Хазяйську специфічність штамів досліджували у вегетаційних дослідах. RFLP аналіз гену rpoВ проводили з використанням рестриктаз MspI, HaeIII та NdeII. Секвенування 16S-23S рДНК здійснювали на автоматичному ДНК-секвенаторі ABI 3130 Genetic Analyser. Результати. Встановлено, що досліджувані ризобії істотно розрізняються за серологічними властивостями і належать до 7 серогруп: КВ11, М8, 1967, 46, В1, В2 та 367а. Мікросимбіонти сої, вигни та машу утворюють групу перехресної інокуляції, проте не спроможні інфікувати люпин. Ризобії люпину B. lupini 367а та Bradyrhizobium sp. ЛД4, навпаки, вступають у симбіотичні взаємовідносини з люпином, але не нодулюють сою. Штам B. japonicum 631 здатний до симбіозу 3 бобовими рослинами різних триб: Phaseoleae та Lupineae. На основі RFLP аналізу rpoB гену мікросимбіонти згрупувались у чотири кластери: I - ризобії вигни, II - бульбочкові бактерії машу та сої, III - повільнорослі бульбочкові бактерії сої, IV - ризобії люпину та інтенсивнорослі ризобії сої. Секвенування 16S-23S рДНК підтвердило належність бульбочкових бактерій сої до виду B. japonicum (генетичні групи USDA 4, USDA 6, USDA 123). До цього ж виду віднесені мікросимбіонти машу (група USDA 4). Вперше з бульбочок вигни отримано ізолят Bradyrhizobium sp. B11, який ідентифіковано як новий вид $B$. diazoefficiens (група USDA 110). Ідентичними виявились ITSрегіони ризобій $B$. lupini 367а та Bradyrhizobium sp. ЛД4. Штам B. japonicum 631 на 100\% подібний зі штамом B. lupini 367a за 16S-23S рДНК і $з$ високою долею ймовірності може бути віднесений 
до виду B. lupini. Висновки. Продемонстровано серологічну різнорідність ризобій з кореневих бульбочок рослин родів Glycine, Vigna та Lupinus. Встановлено, що мікросимбіонти сої, вигни та машу належать до однієї групи перехресної інокуляції. Секвенування 16S-23S рДНК дозволило віднести досліджувані штами до різних генетичних груп та ідентифікувати їх як B. japonicum, B. diazoefficiens та B. lupini. Виявлено, що серологічне групування бульбочкових бактерій співпадає з генетичним (rрoB ген і ITS регіон) групуванням, a їх хазяйська специфічність пов'язана з видовою належністю.

Ключові слова: Bradyrhizobium japonicum, B. diazoefficiens, B. lupini, RFLP аналіз, 16S-23S рДНК, гроВ ген, соя, вигна, маш, люпин.

1. Jordan D. Transfer of Rhizobium japonicum Buchanan 1980 to Bradyrhizobium gen nov., a genus of slow-growing, root nodule bacteria from leguminous plants. Int J Syst Evol Microbiol. 1982; 32(1):136-9. https://doi. org/10.1099/00207713-32-1-136.

2. de Souza JAM, Alves LMC, de Mello Varani A, de Macedo Lemos EG. The family Bradyrhizobiaceae. In: The Prokaryotes, Eds.: E. Rosenberg, EF. DeLong, S. Lory, E. Stackebrandt, F. Thompson. Springer: Berlin/Heidelberg, Germany; 2014. https://doi. org/10.1007/978-3-642-30197-1_253.

3. Kuykendall LD, Saxena B, Devine TE, Udell SE. Genetic diversity in Bradyrhizobium japonicum Jordan 1982 and a proposal for Bradyrhizobium elkanii sp. nov. Can J Microbiol. 2011; 38(6):501-5. https://doi.org/ 10.1139/m92-082.

4. Xu LM, Ge C, Cui Z, Li J, Fan H. Bradyrhizobium liaoningense sp. nov. isolated from the root nodules of soybeans. Int J Syst Bacteriol. 1995; 45:706-11. https://doi.org/10. 1099/00207713-45-4-706.

5. Yao ZY, Kan FL, Wang ET, Wei GH, Chen WX. Characterization of rhizobia that nodulate legume species of the genus Lespedeza and description of Bradyrhizobium yuanmingense sp. nov. Int J Syst Evol Microbiol. 2002; 52:2219-30. https://doi. org/10.1099/00207713-52-6-2219.
6. Avontuur JR, Palmer M, Beukes CW, Chan WY, Coetzee MPA, Blom J, Stępkowski T, Kyrpides NC, Woyke T, Shapiro N, Whitman WB, Venter SN, Steenkamp ET. Genome-informed Bradyrhizobium taxonomy: where to from here? Syst Appl Microbiol. 2019. https:// doi.org/10.1016/j.syapm.2019.03.006.

7. Stepkowski T, Banasiewicz J, Granada CE, Andrews M, Passaglia LM. Phylogeny and phylogeography of rhizobial symbionts nodulating legumes of the tribe Genisteae. Genes. 2018; 9(3):163. https://doi.org/10.3390/ genes 9030163 .

8. Silva FV, Simões-Araújo JL, Silva Júnior JP, Xavier GR, Rumjanek NG. Genetic diversity of Rhizobia isolates from Amazon soils using cowpea (Vigna unguiculata) as trap plant. Brazil J Microbiol. 2012; 43:682-91. https:// doi.org/10.1590/S1517-83822012000200033.

9. Velázquez E, Valverde A, Rivas R, Gomis V, Peix Á, Gantois I, Igual JM, León-Barrios M, Willems A, Mateos PF, Martínez-Molina E. Strains nodulating Lupinus albus on different continents belong to several new chromosomal and symbiotic lineages within Bradyrhizobium. Antonie van Leeuwenhoek. 2010; 97:363-76. https://doi.org/10.1007/s10482010-9415-7.

10. Delamuta JRM, Ribeiro RA, Ormeño-Orrillo E, Melo IS, Martınez-Romero E, Hungria M. Polyphasic evidence supporting the reclassification of Bradyrhizobium japonicum group Ia strains as Bradyrhizobium diazoefficiens sp. nov. Int J Syst Evol Microbiol. 2013; 63:3342-51. https://doi.org/10.1099/ ijs.0.049130-0.

11. Peng GX, Tan ZY, Wang ET, Reinhold-Hurek B, Chen WF, Chen WX. Identification of isolates from soybean nodules in Xinjiang Region as Sinorhizobium xinjiangense and genetic differentiation of $S$. xinjiangense from Sinorhizobium fredii. Int J Syst Evol Microbiol. 2002; 52:457-62. https://doi. org/10.1099/00207713-52-2-457.

12. Chen WX, Wang ET, Li YB, Chen XQ, Li Y. Characterization of Rhizobium tianshanense sp. nov. moderately and slowly growing nod- 
ule bacterium isolated from an acid saline environment in Xinjiang, People's Republic of China. Int J Syst Bacteriol. 1995; 45:153-9. https://doi.org/10.1099/00207713-45-1-153.

13. Fotev YuV, Sidorova KK, Novikova TI, Belousova VP. [Study of nodulation and nitrogen fixation in two cowpea Vigna unguiculata (L.) Walp. cultivars inoculated with different strains of Bradyrhizobium sp.] Vavilov Journal of Genetics and Breeding. 2016; 20(3):34854. https://doi.org/10.18699/VJ16.099. Russian.

14. Tampakaki AP, Fotiadis CT, Ntatsi G, Savvas D. Phylogenetic multilocus sequence analysis of indigenous slow-growing rhizobia nodulating cowpea (Vigna unguiculata L.) in Greece. Syst Appl Microbiol. 2017; 40(3):179-89. https://doi.org/10.1016/j.syapm.2017.01.001.

15. Mpepereki S, Wollum AG, Makonese F. Diversity in symbiotic specificity of cowpea rhizobia indigenous to Zimbabwean soil. Plant Soil. 1996; 186:167-71. https://doi.org/ 10.1007/BF00035071.

16. Peix A, Ramírez-Bahena MH, Flores-Félix JD, Alonso de la Vega P, Rivas R, Mateos PF, Igual JM, Martínez-Molina E, Trujillo ME, Velázquez E. Revision of the taxonomic status of the species Rhizobium lupini and reclassification as Bradyrhizobium lupini comb. nov. Int J Syst Evol Microbiol. 2015; 65:1213-19. https://doi.org/10.1099/ijs.0.000082.

17. Duran D, Rey L, Sanchez-Canizares C, Navarro A, Imperial J, Ruiz-Argueso T. Genetic diversity of indigenous rhizobial symbionts of the Lupinus mariaejosephae endemism from alkaline-limed soils within its area of distribution in Eastern Spain. Syst Appl Microbiol. 2013; 36:128-36. https://doi.org/10.1016/j. syapm.2012.10.008.

18. El Hilali I, El Jamali J, Thami Alami I, Filali Maltouf A. Characterization and biodiversity of a fast-growing rhizobacterial population nodulating lupine in Morocco. Int J New Tech Res. 2016; 12:27-37.

19. Pudełko K. Diversity among field populations of bacterial strains nodulating lupins in Poland. Fragm Agron. 2010; 7:107-16.
20. Krutylo DV, Nadkernychna OV, Kovalevska TM, Patyka VP. [Biological diversity of soybean nodule bacteria in soils of Ukraine]. Mikrobiol Z. 2008; 70(6):27-34. Ukrainian.

21. Krutylo DV, Volkova IV. [Serological diversity of soybean nodule bacteria in Ukraine soils]. Agroecological Journal. 2012; 4:66-71. Ukrainian.

22. Kots SYa, Morgun VV, Patyka VF, Datsenko VK, Krugova ED, Kyrychenko EV et al. [Biological nitrogen fixation: legume-rhizobial symbiosis]. Vol. 1. Kiev: Logos, 2010. Russian.

23. Kebot E, Meyer B. [Experimental immunology]. Moscow: Medicina Publ.; 1968. Russian.

24. Hardy RWF, Holsten RD, Jackson EK, Burns $\mathrm{RC}$. The acetylene-ethylene assay for nitrogen fixation: laboratory and field evaluation. Plant Physiol. 1968; 43(8): 1185-1207. https://doi. org/10.1134/S207905971502005710.1104/ pp.43.8.1185

25. Beringer JE. R1 transfer in Rhizobium leguminosarum. J Gen Microbiol. 1974; 84:188-98. https://doi.org/10.1099/00221287-84-1-188.

26. Normand P, Ponsonnet C, Nesme X, Neyra M, Simonet P. ITS analysis of prokaryotes. Mol Microbial Ecology Manual. 1996; 5(3-4):112.

27. Ponsonnet $\mathrm{C}$, Nesme $\mathrm{X}$. Identification of Agrobacterium strains by PCR-RFLP analysis of pTi and chromosomal regions. Arch Microbiol. 1994; 161:300-9.

28. Thompson JD, Higgins DG, Gibson TJ. CLUSTAL W: improving the sensitivity of progressive multiple sequence alignment through sequence weighting, position-specific gap penalties and weight matrix choice. Nucleic Acids Res. 1994; 22:4673-80. https:// doi.org/10.1093/nar/22.

29. Tamura K, Stecher G, Peterson D, Filipski A, Kumar S. MEGA6: Molecular Evolutionary Genetics Analysis Version 6.0. Mol Biol Evol. 2013; 30:2725-29. https://doi.org/ 10.1093/ molbev/mst197.

30. Nei M, Kumar S. Molecular evolution and phylogenetics. Oxford, UK: Oxford University Press; 2000. 
31. Martens M, Dawyndt P, Coopman R, Gillis M, De Vos P, Willems A. Advantages of multilocus sequence analysis for taxonomic studies: a case study using 10 housekeeping genes in the genus Ensifer (including former Sinorhizobium). Int J Syst Evol Microbiol. 2008; 58:20014. https://doi.org/10.1099/ijs.0.65392-0.

32. Rivas R, Martens M, De Lajudie P, Willems A. Multilocus sequence analysis of the genus Bradyrhizobium. Syst Appl Microbiol. 2009; 32:101-10. https://doi.org/10.1016/j. syapm.2008.

33. Spaink HP, Kondorosi A, Hooykaas P. [The Rhizobiaceae: Molecular biology of model plant-associated bacteria]. St.-Petersburg: Biont; 2002. Russian.

34. Safronova VI, Chizhevskaya EP, Belimov AA, Pavlova EA. [Taxonomy of microsymbionts of Hedysarum and Astragalus basing on ribosomal RNA genes sequencing]. Agricultural Biology. 2011; 3:61-4. Russian. https://doi. org/10.15389/agrobiology.2017.5.1004eng.

35. Wang ET, Tian CF, Chen WF, Young JPW, Chen WX. Ecology and Evolution of Rhizobia: Principles and Applications. Singapore: Springer Verlag; 2019.

36. Sikora S, Redzepović S. Genotypic characterization of soybean rhizobia. Food Technol Biotechnol. 2003; 41:61-7.
37. Appunu C, N'Zoue A, Laguerre G. Genetic diversity of native bradyrhizobia isolated from soybeans (Glycine max L.) in different agricultural-ecological-climatic regions of India. Appl Environ Microbiol. 2008; 74 (19):59916. https://doi.org/10.1128/AEM.01320-08.

38. Chidebe IN, Jaiswal SK, Dakora FD. Distribution and phylogeny of microsymbionts associated with cowpea (Vigna unguiculata) nodulation in three agroecological regions of Mozambique. Appl Environ Microbiol 2018; 84(2):1-25. https://doi.org/10.1128/ AEM.01712-17.

39. Saeki Y. Characterization of soybean-nodulating rhizobial communities and diversity. In: Aleksandra S, editor. [Soybean-molecular aspects of breeding]. Rijeka: Intech; 2011. p. 163-84. https://doi.org/10.5772/14417.

40. van Berkum P, Fuhrmann JJ. Evolutionary relationships among the soybean bradyrhizobia reconstructed from $16 \mathrm{~S}$ rRNA gene and internally transcribed spacer region sequence divergence. Int J Syst Evol Microbiol. 2000; 50(6):2165-72. https://doi. org/10.1099/00207713-50-6-2165.

41. Ahmad MH, Eaglesham ARJ, Hassouna S. Examining serological diversity of "cowpea" rhizobia by the ELISA technique. Archives of Microbiology. 1981; 130:281-7. http://dx.doi. org/10.1007/BF00425941.

Отримано 14.06.2019 